\title{
GIS-Based Vulnerability Assessment of the Semi-Arid Ecosystem to Land Degradation: Case Study of Sokoto-Rima Basin
}

\author{
Saheed Adekunle Rajii,2, Shakirudeen Odunuga², Mayowa Fasona ${ }^{2}$ \\ ${ }^{1}$ Department of Environmental Management \& Toxicology, Federal University of Petroleum Resources, Effurun, Nigeria \\ ${ }^{2}$ Department of Geography, University of Lagos, Lagos, Nigeria \\ Email: raji.saheed@fupre.edu.ng, sodunuga@unilag.edu.ng,mfasona@unilag.edu.ng
}

How to cite this paper: Raji, S.A., Odunuga, S. and Fasona, M. (2019) GIS-Based Vulnerability Assessment of the Semi-Arid Ecosystem to Land Degradation: Case Study of Sokoto-Rima Basin. Journal of Environmental Protection, 10, 1224-1243. https://doi.org/10.4236/jep.2019.1010073

Received: August 1, 2019

Accepted: October 6, 2019

Published: October 9, 2019

Copyright $\odot 2019$ by author(s) and Scientific Research Publishing Inc. This work is licensed under the Creative Commons Attribution International License (CC BY 4.0).

http://creativecommons.org/licenses/by/4.0/

\begin{abstract}
Land degradation is one of the most ubiquitous environmental challenges affecting the semi-arid ecosystems of the world and the Sokoto-Rima basin is not immune to this. In this study, we evaluated vulnerability of the Sokoto-Rima basin to land degradation by combining remote sensing and geographic information system technologies. An appraisal model was developed for the identified nine variables, whose weights were ascertained by the analytical hierarchy process. Using this model, we examined the spatiotemporal distribution of vulnerability to land degradation stimulated by climate change from 2002 to 2015 . Largely, the basin is extremely vulnerable to land degradation with roughly $88 \%$ of the land area in 2002, 2012 and 2015 while areas with low vulnerability were just $1.52 \%, 1.48 \%$ and $1.51 \%$ respectively. Geographically, there exists a north-south vulnerability index dichotomy as the index increases northwards. Also, integrated vulnerability index showed that the entire basin is getting exposed to the vagaries of climate change that stimulates land degradation. Large-scale resilience projects such as greening and integrated shelter-belts and woodlots can be implemented in the long run as existing ones are inadequate to address the observed degradation.
\end{abstract}

\section{Keywords}

Vulnerability, GIS, Semi-Arid Ecosystem, Sokoto-Rima Basin, AHP

\section{Introduction}

Globally, the semi-arid ecosystem, a key component of the global drylands, is at the edge of continuous environmental disturbances [1] [2] [3] [4]. It has been subjected to series of environmental problems most of which are protogeographic in 
spatial manifestations and protohistoric in temporal dimensions [5] [6] [7]. Land degradation is one of the numerous environmental problems known with the semi-arid ecosystem; one of the top ten major problems identified with the ecosystem [8]. These notwithstanding, the semi-arid remains one of the richest ecosystems of the world owing to its natural abundance of eco-geographic endowments that aid agriculture [9] and supports human existence having one of the highest rates of population growth in the world [10].

The Sokoto-Rima basin falls entirely within the semi-arid of West Africa. Sufficient evidence in literature suggests that this basin lies within the global environmental hotspots owing to its climatic volatility and incessant land degradation attributed to both anthropogenic and natural factors [11] [12] [13] [14] [15]. [11] emphasized that there is manifestation of extremes in their records of temperature and rainfall events typified by seasonal and decadal droughts and flooding as well as heat wave running through most of the settlements in the basin. [12] affirmed that there should be measures aimed at addressing these climate extremes. [13] claimed that extreme rainfall and temperature correlate with available water in the basin with significant implications for survival. [14] therefore suggested that environmental resources within the basin should be managed sustainably and diversification of rural economy should be encouraged. [15] stated that agricultural intensification should be checked via diversified and managed agriculture in conjunction with climate-smart agrarian practices. In this study, we adopt the definition of land degradation sequel to the discourse of [16] which states that degradation in the Sokoto-Rima basin manifests in form of erosion and overgrazing, land exposure/desiccation, and loss of prime agricultural land.

To wit, vulnerability as a methodical term is profoundly rooted in natural hazard research and geography [17]. However, the term has diffused to other fields of scientific enterprises such as ecological assessment, climate change adaptation, public health, disaster risk management, livelihood assessment, natural resource management, sustainability science, land change, environmental change, urban planning, food security and poverty, epidemiology and several other emerging disciplines [18].

There is no universally acceptable definition of vulnerability as scholars often express various ontologies that connect their research to their respective inclinations. Vulnerability according to [4] is the degree to which a system is susceptible to, and unable to cope with, adverse effects of climate change, including climate variability and extremes. This definition expresses further that vulnerability is a function of character, magnitude and the rate of climate change and variation to which a system is exposed. Focusing on systems, [19] affirmed that severity of the specific stressful event and the degree of adaptive capacity are the two factors that determine the extent of vulnerability of a system. From the [4] definition and the system approach, three components of vulnerability can be excised, these are exposure, sensitivity and adaptive capacity. When admixed with [19], it becomes much clearer that these components drive the susceptibili- 
ty of a system to climatic change and variability. Hence, a system becomes vulnerable if it possesses high levels of exposure, if it is highly sensitive and if its adaptive capacity to climate change is very low [20]. These tripartite components were adopted in this study as a means of establishing the extent of ecosystem vulnerability of the Sokoto-Rima basin.

Similarly, [21] described vulnerability as inherent characteristics of a system that create the potential for harm but are independent of the probabilistic risk of occurrence of any particular hazard or extreme event. This assertion establishes the fact that vulnerability is a function of inbuilt traits of system that create the likelihood of occurrence of an extreme event despite their autonomous nature to the manifestation of such phenomenon. This definition also forms a critical aspect of this study as some traits of the semi-arid ecosystem are independent of the occurrence of climate extremes. [22] and [23] have provided meticulous review and analysis of vulnerability concepts and applications for global and place-based contexts. Within the study area and most of northern Nigeria, climate change studies have been centralised on perception studies, adaptation and mitigation studies which were either concentrated on farmers' perception [15] or riverine communities [14] [24].

The utility of geospatial technology to ascertain level of vulnerability to either land degradation, climate change or both have been very limited. Elsewhere, geographic information systems (GIS) have been used extensively to study land degradation [7], desertification risk assessment [5] as well as copious examples of changes in land use and land cover. Within the Sokoto-Rima basin, [25] utilised SPOT NDVI to simulate movement of desertification while [26] employed MODIS-NDVI to monitor the health status of several ecosystems identified in the area. The outcome of these studies was used as mere indicators of vulnerability and not a detailed assessment in which values will be computed and mapped across the landscape of the basin. Also, vulnerability studies often require quantitative approaches nonetheless the previous methods such as [14] and [24] were entirely qualitative through the use perception studies with questionnaire administration.

This aim of consequently is to assess the vulnerability of the semi-arid ecosystem of the Sokoto-Rima basin to climate change driven land degradation. Associated objectives include development of ecosystem vulnerability appraisal model aided by remote sensing and GIS tools. Usage of analytic hierarchy process (AHP) to generate variable weights to support the mapping of vulnerability index ascertains the dynamics of vulnerability indices from 2002 to 2015 in the basin based on integrated vulnerability index.

\section{Materials and Methods}

\subsection{Study Area}

The Sokoto-Rima Basin is an international (trans-boundary) basin that traverses three countries: Nigeria, Benin and Niger. However, the study area is spatially 
restricted to the borders of Nigeria, covering the entire boundaries of Sokoto, Kebbi, and Zamfara, States. It defines hydrological basin of the sudano-sahelian eco-climatic region of northwestern Nigeria. Geographically, it stretches approximately from Latitudes $10^{\circ} 32^{\prime} 35^{\prime \prime}$ to $13^{\circ} 32^{\prime} 55^{\prime \prime}$ North of the equator and Longitudes $3^{\circ} 30^{\prime} 30^{\prime \prime}$ to $8^{\circ} 1^{\prime} 15^{\prime \prime}$ East of the Greenwich meridian occupying land area of $94,026.5 \mathrm{~km}^{2}$ (Figure 1 ).

Physiographically, the basin is dominated by tripartite units-the eastern uplands, the central Sokoto plains, and the wet lowland of the Niger with the lower Rima valley. The Sokoto-Rima River Basin is drained by the Sokoto River-a key tributary of the extensive River Niger basin (Figure 1) Rima, Zamfara and $\mathrm{Ka}$ are the main tributaries of the Sokoto River. The watershed flows in an eastern-northern direction, through a series of gentle slopes towards the northwest. Towards the north, Rima River joins abutting Sokoto town connecting rivers Zamfara and Ka thereafter connecting the Niger River. There are series of interconnecting river systems with tributaries and distributaries within the basin. At the basin eastern source, it is joined by Konni River, the basin depicts traces of seasonality, and as it flows towards the western direction it becomes perennial owing to inputs from sub-surface flows from the vast Iullemeden geologic basin [27].

The study area is governed by a semi-arid/savanna climate of tropical continental type. This is symbolised by its considerable spatial and seasonal variation characteristics. Rainfall distribution, over a period of 70 years, depicts a mean annual value of $350 \mathrm{~mm}$ (Illela) in the north to $895 \mathrm{~mm}$ (Yelwa) in the south. Over the entire area, the rainfall hydrograph displays unimodal peak which is recorded usually recorded in August. The rainy season, which usually starts from May or June of each year, lasts till September or early October depending on the rainfall pattern for that year. Between November and March is the dry (Harmattan) period, which is completely without rain, but dominated by dust-laden and cold winds blow in from the northwest. This phenomenon is influenced by the intertropical discontinuity (ITD). The departure of Harmattan and the onset of rain are usually marked by a hot sunny season having temperature range of $37^{\circ} \mathrm{C}-42^{\circ} \mathrm{C}$ with the highest temperature in April. Diurnal temperature varies from $21^{\circ} \mathrm{C}-27^{\circ} \mathrm{C}$ and class $\mathrm{A}$ evaporation ranges from less than $2000 \mathrm{~mm}$ per annum to $2500 \mathrm{~mm}$ per annum in the extreme north with potential evapotranspiration far exceeding precipitation [11]. As rainfall is concentrated within 3 - 5 months, a periodic, short-lived but strong surface runoff exists; resulting in high stream discharge is usually experienced. Generally, the advancement of the desert southwards that is accompanying natural climatic fluctuations both make the whole of the sudano-sahelian savanna belt subject to aridity. Without doubt, these climatic fluctuations have great impact on the ecosystem.

Basement complex rocks and sedimentary rocks define the geology of the study area. The basement complex rock of pre-Cambrian age constitutes plateau and highland of the eastern end of the area. The extensive central plain and its 


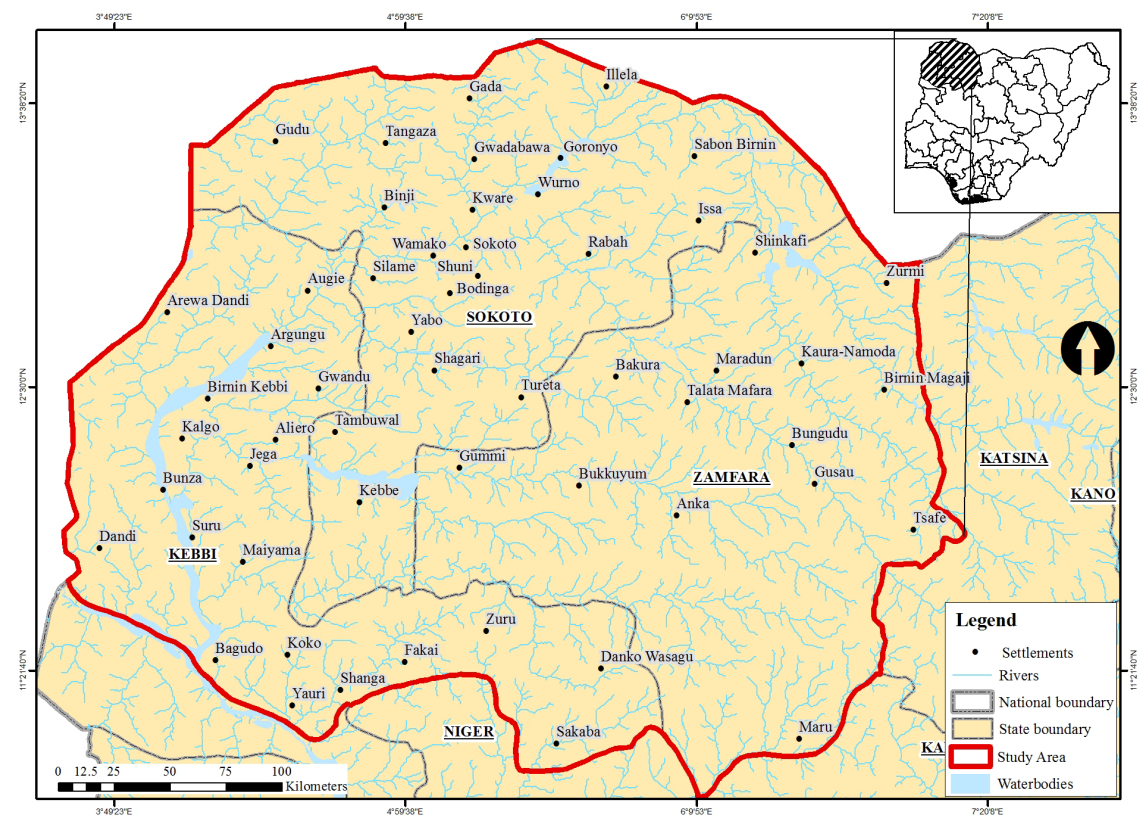

Figure 1. The study area (Sokoto-Rima basin). Source: Laboratory of Remote Sensing \& GIS, Department of Geography, University of Lagos.

rolling terrain describes the sedimentary surficial geology. To a great extent, this contributes to the groundwater level is reported as $50-100 \mathrm{~m}$ below the ground in Sokoto-Rima Basin [28]. Soils are mostly sandy as related to the sedimentary geology and alluvial soils are found within the floodplains of the rivers and are rich in minerals to support crop production.

The study area is archetypally agrarian hence settlement pattern is majorly rural. Urban and sub-urban settlements are mostly restricted to capital cities, commercial centres and local government headquarters some of which are major towns. Crop cultivation and animal husbandry remain the lifeblood of the economy and the basic sources of livelihood for the dwellers. Dominant crops cultivated within the upland areas are particularly grains such as millet, corn and sorghum, as well as legumes such as beans and groundnut. Also, irrigation farming is widespread in lowland areas and floodplains where tomatoes, onions, garlic, and majorly rice are cultivated. There are traces of artisanal fishing along the major rivers-Sokoto and Rima as well as on few ephemeral streams. Although dominated by subsistence practices, some commercial groups can be identified in the form of main crop cultivation clusters essentially tomato and rice. Cattle, goats, sheep are reared as domestic and for commercial purposes. Uncontrolled practices however have led to instances of overgrazing and destruction of designated reserves, parks, woodlands and even clashes with crop farmers.

\subsection{Data Description, Algorithms and Sources}

The CCI (Climate Change Initiative) landcover, a pre-classified remotely sensed data of the study area, was acquired from the portal of European Space Agency 
(ESA). The multi-year dataset was developed from integration of composite and mosaicked multi-sources specifically AVHRR (Advanced Very High Resolution Radiometer), Envisat MERIS (Medium Resolution Imaging Spectrometer), PROBA-V (Project for On-Board Autonomy-Vegetation), Sentinel-3 Ocean and Land Colour Instrument (OLCI) and Sea and Land Surface Temperature Radiometer (SLSTR). It possesses a spatial resolution of 300 metres and dynamic range of 8-bits, making the data suitable for regional analysis. The inbuilt legend data was developed and structured after the CORINE Landcover Classification System. Images of static years 2002, 2012 and 2015 were acquired for this study. Subsequently, a follow-through image reclassification task was conducted. This task was aimed at re-ordering the pixels to match the on-the-ground scenario and redraft the pixels to mirror the subject of analysis based on the FAO (Food and Agricultural Organization) Land Cover Classification System. Table 1 displays the preliminary pixel details of the landcover images, the reclassification task and the new pixel codes.

Elevation data was extracted from ALOS World 3D Digital Surface Model (DSM) data sourced from the archives of Japan Aerospace Exploration Agency (JAXA) https://www.eorc.jaxa.jp/. It has a horizontal resolution smoothened to 30 metres and the gridded image was developed from satellite-based data collection by JAXA in 2014. It has dynamic range of 32 bits which permits detection of high resolution DSM of several locations globally.

Table 1. Landcover image reclassification.

\begin{tabular}{|c|c|c|c|}
\hline \multicolumn{2}{|c|}{ Initial Pixel Details } & \multicolumn{2}{|c|}{ Pixel Reclassification } \\
\hline Old & ESA CCILI $C$ Deccrintion & New & Landcover \\
\hline Pixel Code & LSA CU1-LC Deschiption & Pixel Code & Class description* \\
\hline 10 & Cropland, rainfed & 10 & Cropland \\
\hline 30 & Mosaic of cropland and natural vegetation & & \\
\hline 90 & Shrub or herbaceous cover & 20 & Agroforestry \\
\hline 40 & Tree cover, broadleaved, open & & \\
\hline 50 & $\begin{array}{l}\text { Mosaic of tree and shrub with herbaceous } \\
\text { cover }\end{array}$ & 80 & Woodland \\
\hline 60 & Shrubland & 30 & Shrubland \\
\hline 70 & Grassland & & \\
\hline 80 & $\begin{array}{l}\text { Sparse vegetation, dominated by grassy and } \\
\text { herbs }\end{array}$ & 40 & Grassland \\
\hline 100 & Settlements & 60 & Settlements \\
\hline 110 & Bare areas & 70 & Bare surface \\
\hline 120 & $\begin{array}{l}\text { Water bodies, open water body, } \\
\text { large dams and reservoirs }\end{array}$ & 50 & Waterbody \\
\hline 20 & Irrigated area and perennially flooded areas & & \\
\hline
\end{tabular}

* Adapted from FAO Land Cover Classification system [29]. 
In the study area, vegetation is essential germane as it defines evidence of environmental safety and ecosystem productivity. Two measures were utilised. First, eMODIS NDVI data was used as indicator vegetation and ecosystem health. The data was sourced from USGS Famine Early Warning System (FEWS) Data for West Africa with spatial resolution of 250 metres through the portal https://earlywarning.usgs.gov/fews/product/451. Second, the concept of potential vegetation was adopted from [30]. As used in this study, potential vegetation was extracted from the landcover data via the aggregation of shrubland, grassland and woodland.

Climate data, rainfall and temperature were obtained from Nigeria meteorological agency NIMET supplemented with data from Princeton University station-based data via the Princeton Climate Analytics (PCA)

https://platform.princetonclimate.com/PCA Platform/. The synoptic stations were located in three countries Nigeria (Sokoto, Yelwa, Birnin Kebbi, Argungu, Gusau, Goronyo, Wurno, Kano, and Kaduna), Benín Republic (Mallanville) and Niger Republic (Dabnou). Mean annual rainfall data for the years 2002, 2012 and 2015 were utilised. Owing to possibility of extremes, mean maximum temperature data was sourced covering the same meteorological periods as that of rainfall. The datasets were converted to raster from points using IDW (inverse distance weighted) algorithm. IDW is a spatial interpolation method that follows the first law of geography which is summarised as events are more autocorrelated than those farther apart, hence this numerical technique was adopted based on the fact each given point has a local influence that shrinks with decreasing space. [31] mathematically expressed this technique as displayed in Equation (1);

$$
Z j=k j \sum_{i=1}^{n}\left(\frac{1}{d i j^{\infty}}\right) z i
$$

where $Z_{j}$ is the spatially predicted value, $d_{i j}$ is the spatial interval between the known and the predicted value, $z i$ is the known value and $k j$ is an adjustment to ensure that the weights add up to unity (1).

Soil data utilised was streamlined to currency and status of the soil within the past decade. Hence, HYSOG Soil Group data sourced from the United States Oak Ridge National Library Distributed Active Archive Centre (ORNL DAAC) through the portal https://daac.ornl.gov/cgi-bin/dsviewer.pl?ds id=1566 was used. The raster data has a spatial resolution of 250 metres and was developed in 2015.

Geology data was sourced from Soil Survey Division of the Federal Department of Agricultural Land Resources (FDAL) Kaduna Nigeria. The data has a scale of 1:650,000 and it covered the study area. It was sourced as analogue data. It was further rasterised for GIS analysis.

Population data was published online by the principal bureau of statistics for Nigeria, the National Bureau of Statistics (NBS) through the web portal http://www.nigerianstat.gov.ng. Density values were calculated using the land area values in $\mathrm{km}^{2}$ from local government area values sourced from the NBS. 
The GIS rasterised computation was based on IDW as earlier described.

GIS procedure of rasterisation of data layers was implemented using ArcGIS 10.6 software supplied by ESRI. All data layers were re-sampled to minimum mapping unit of 300 metres and equal cell dimensions to ensure mapping consistency and regularity. Also, the data were also referenced to UTM $31 \mathrm{~N}$ projection for the northern hemisphere where the study area lies.

\subsection{Assessment of Ecosystem Vulnerability}

\subsubsection{Variable System}

Ecosystem vulnerability as influenced by climate change is composed of three environmental dimensions: exposure, sensitive and adaptive capacity [4]. The dimensions explain the underlying processes that government ecosystem vulnerability to degradation. In this study, three underlying processes were identified based on literature investigations of the different social, physical, socioeconomic and environmental indicators. Each of these has componential geo-environmental variables that explain the dynamics of each dimension to stimulate land degradation.

To wit, exposure explains the natural dimension that directly influence land degradation and it is influenced by climatic extremes, alongside other environmental factors of the study area [4]. The reality of exposure component of vulnerability assessment in the basin is undeniable. Studies have shown that climate extremes correlate with decline in vegetation health [26] and southward migration of the Sahara [25]. [16] emphasised that the Sokoto-Rima basin has experienced contrasting changes driven by acute landcover transformation and climatic extremes leading to manifestation of series of land degradation. Consequently, elevation, precipitation, temperature, soil and geology were identified as exposure variables in this study.

Sensitivity expresses direct factors that respond to changes in the climatic dynamics in the area. These are mainly vegetation and landcover components of the terrestrial ecosystem. In this study, index of vegetation (NDVI), landcover and areas of potential vegetation [30] are variables of sensitivity. These are mainly indicators of ecosystem status, health and resilience in the face of daunting climate extremes. Indeed, the semi-arid ecosystems globally rely on the stabilisation role played by vegetation owing to its dual role of resilience and response on imprints of climate change [32].

Adaptive capacity is a reflection of human response to adapt to climatic dynamics and variability in order to alleviate probable damages, cope with extremes and take advantage of possible opportunity [4]. Population density was utilised as a measure of adaptive capacity for this study.

The combination of these dimensions and their respective variables birthed the development of the designed appraisal model contained in Table 2.

\subsubsection{Appraisal Model}

To express the ecosystem vulnerability of the Sokoto-Rima basin, a procedural 
framework was designed which indicates the workflow of the study in line with the stepwise GIS process of generating the index values. This is illustrated in Figure 2 which displays the overall process of data collection to analysis and vulnerability index map development. However, an essential aspect of this is the expressive definition of the appraisal model of the study. This is based on the variables defined in Table 2 which were developed as individual thematic raster data with respective values. These variables were further normalised with values ranging from 0 to 1 irrespective of their values using the Equation (2)

$$
\rho_{i}=\left(x_{i}-x_{\min }\right) /\left(x_{\max }-x_{\min }\right)
$$

Table 2. Evaluation of variable system for the assessment of vulnerability to land degradation in Sokoto-Rima basin.

\begin{tabular}{cccc}
\hline Dimension & Variables & AHP Weight & $\begin{array}{c}\text { Linkage with Land } \\
\text { Degradation }\end{array}$ \\
\hline Elevation & 0.036093 & Neutral \\
Precipitation & 0.208501 & Positive \\
Exposure & Temperature & 0.162914 & Positive \\
& Soil & 0.135433 & Positive \\
Geology & 0.050816 & Positive \\
Sensitivity & Vegetation index (NDVI) & 0.148567 & Negative \\
& Potential vegetation & 0.157346 & Negative \\
& Landcover & 0.078224 & Positive \\
Adaptive Capacity & Population density & 0.022106 & Positive
\end{tabular}
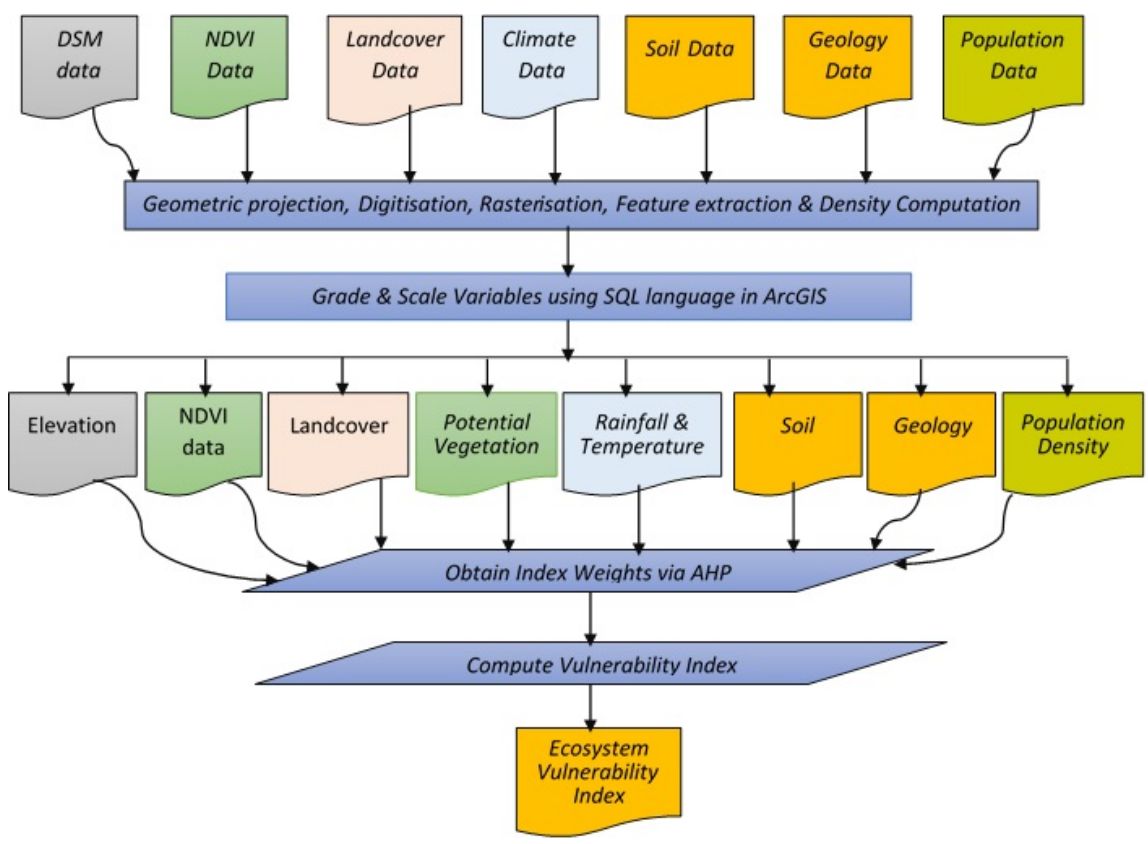

Figure 2. Illustration of workflow designed for the appraisal model for the study which showcases the entire process of data sourcing, processing, archival of index layers via GIS and the ecosystem vulnerability index computation. 
where $x_{i}$ is the value of cell $i, x_{\max }$ and $x_{\min }$ are the minimum and maximum values within the entire data. It should be noted the degradation influence guided the implementation of the equation and where negative values were recorded, the value is subtracted from 1 (to get a positive integer). SQL was used in Raster Calculator sequentially for each variable to compute the map outcome across each dimension.

Several possible ways have been devised to generate variable weights. Identified examples include Delphi [33], the analytic hierarchy process (AHP) [34], entropy [35] and fuzzy clustering [36]. Out of these measures, AHP possesses unique ability for multicriteria decision making method which permits series of pairwise comparisons between assessed variables to generate a ranking of the variables. AHP also has the ability to effectively combine both quantitative and qualitative variables, coordinate different opinions of stakeholders, combine differential expert judgments, and presents a suitable integration and aggregation of these views in a scalable manner for apt decision making. It has wide range of utilisation in GIS-based decision making inquiry [32]. In this study, opinions of expert on the dynamics of environmental changes affecting the Sokoto-Rima basin as well as impact of climate change on the nature and dynamics of the basin was sought via the instrumentation of Key Informants Interview (KII). The experts were drawn from diverse professions specifically agriculture, water resources, integrated basin management, climate change and land change scientists in universities, government institutions and private practices, and non-governmental organisations (NGOs). These opinions were weighted based on the identified variables and dimensions stated in Table 2. Hence, variable weights were computed based on the analytic hierarchy process (AHP) using attached AHP algorithm in the GIS software. Subsequently, the index of consistency (CI) and consistency ratio (CR) were computed to test the generated results. The computed CI yields 0.081 and $C R=0.056, \mathrm{CR}$ value that is $\leq 0.1$ is considered acceptable [37], hence the outcome is acceptable and adopted for the study.

\subsection{Ecosystem Vulnerability Index}

Summation of the three dimensions presented in Table 2 provides the vulnerability index. Following the stated procedure, the vulnerability index should a raster with continuous range of values between 0 and 1 . These represent varying degree of vulnerability to land degradation in the basin. In order to ensure logical scaling of index interpretation, the raster values were subjected to classification using Jenks natural breaks classification which is a systematic hierarchy of values that leverages on statistical variances within the recorded values. Table 3 presents the summary of the vulnerability index values, and their respective index descriptions. Therefore, ecosystem vulnerability index (EVI) is expressly defined in Equation (3).

$$
\mathrm{EVI}=\left(\sum_{j=1}^{n}\left(e_{j} w_{j}\right)\right)+\left(\sum_{k=1}^{n}\left(s_{k} w_{k}\right)\right)+\left(\sum_{m=1}^{n}\left(a_{m} w_{m}\right)\right)
$$


Table 3. Degrees of EVI in Sokoto-Rima basin to degradation.

\begin{tabular}{|c|c|c|}
\hline Vulnerability & EVI range of values & Index description \\
\hline Extremely high & 0.00 & $\begin{array}{l}\text { Totally degraded ecosystem with deteriorated soil and } \\
\text { prone to aridity, vegetation is far less than }<1 \% \text { of the } \\
\text { land area }\end{array}$ \\
\hline Very high & $0.00-0.24$ & $\begin{array}{l}\text { Extremely unstable ecosystem, with poor resistance to } \\
\text { degradation, and very low vegetation cover }(<5 \%) \text { with } \\
\text { evidence of deteriorated soil }\end{array}$ \\
\hline High & $0.24-0.31$ & $\begin{array}{l}\text { Unstable ecosystem, with poor resistance to } \\
\text { degradation and low vegetation cover ( } 5 \%-10 \%) \text {, a } \\
\text { desert-prone area, exposed area under influence of } \\
\text { dune dynamics }\end{array}$ \\
\hline Moderate & $0.31-0.38$ & $\begin{array}{l}\text { Somewhat unstable ecosystem, with relatively low } \\
\text { vegetation cover }(10 \%-20 \%) \text { and resistance to } \\
\text { degradation, evidences of large dune collection } \\
\text { depicting desert-prone landscape }\end{array}$ \\
\hline Low & $0.38-0.51$ & $\begin{array}{l}\text { Relatively stable ecosystem, with relatively high } \\
\text { vegetation cover }(20 \%-40 \%) \text { and possible resistance } \\
\text { to degradation, semi-exposed soil, spots of shrubs, and } \\
\text { grasses }\end{array}$ \\
\hline Very low & $>0.51$ & $\begin{array}{l}\text { Stable ecosystem, with relatively high vegetation } \\
\text { cover }>40 \% \text { and high resistance to degradation. }\end{array}$ \\
\hline
\end{tabular}

Source: Adapted from [38].

where, $e_{j}$ is standardised value for exposure variables, $w_{j}$ is the resultant weight, $s_{k}$ is the standardised value for sensitivity variables, $w k$ is the weight of the variable, $a_{m}$ is the standardised value for adaptive capacity variable and $w_{m}$ is the associated weight. Table 3 details the vulnerability index value and its interpretation.

To compute integrated vulnerability index which is the accretion of all vulnerability indices for a given year, Equation (4) was utilised. The equation is described thus:

$$
\mathrm{IVI}=\sum_{r=1}^{6} P_{r}\left(A_{r} / S\right)
$$

where $r$ is the status levels of the ecosystem vulnerability (6), $A_{r}$ is the area of the basin occupied by the specific vulnerability grade $r, S$ is the total area of the ba$\sin , P_{r}$ is the grade value of the status levels (very low $=6$, low $=5$, moderate $=4$, high $=3$, very high $=2$, extremely high $=1$ ) and $I V I$ is the integrated vulnerability index for a given year of assessment in the study area. Meanwhile, IVI variation is the difference between IVI value for a given year and the preceding or succeeding year. This is used to ascertain the level of improvement or degradation in the ecosystem indicated by negative or positive vulnerability value respectively.

\section{Results and Discussion}

\subsection{Ecosystem Vulnerability of the Basin}

Results of the ecosystem vulnerability to land degradation in the Sokoto-Rima 
basin are spatially displayed in Figures 3-5. Common to the three period of study is the preponderance of extremely high vulnerability index. Apart from this, the index ranges between 0.29 and above 0.93 in 2002 . These values also depict some location references. Most of the northern axes are dominated by scattered index ranging from 0.29 to 0.57 in the northeastern axis of the study area. High vulnerability values were recorded in areas such as Gada, Gudu, Illela, Binji, Tangaza, and parts of Rabah. Mid-index values of 0.57 to 0.74 were recorded in Maradun, Talata-Mafara, and Zurmi. Low vulnerability however, were recorded in some eastern axis such as Bungudu, Birnin-Magaji, Kaura-Namoda and parts of Tsafe. Similar values were recorded in Danko Wasagu, Sakaba, Fakai all in Zamfara State.

A decade after the 2002 scenario, the low ecosystem vulnerability index improved slightly from 0.93 to 0.96 (Figure 4). This progressive improvement in ecosystem vulnerability was observed in the eastern axis which was previously dominated by mid-index values to lower index. Also, the northern axis also recorded slight improvements in the index where the value improves to $0.45-0.63$ range. Specifically the index improved in areas such as Gada, Gwadabawa and Kware.

By 2015, the vulnerability ranged from 0 to above 0.96 (Figure 5). This is the same value with 2012 however, traces of locational differences are observed across the basin. In the northern axis of the basin, the index improved slightly with a range of 0.26 to 0.52 . This is noticed in Goronyo, Wurno, Sabon-Birnin, Illela, Sabon Birnin. Index 0.63 - 0.78 was observed in areas such as Shinkafi, Kaura Namoda and parts of Birnin Magaji compared to average index of 0.78 observed in 2012 in these areas. This points to a gradual increase in vulnerability

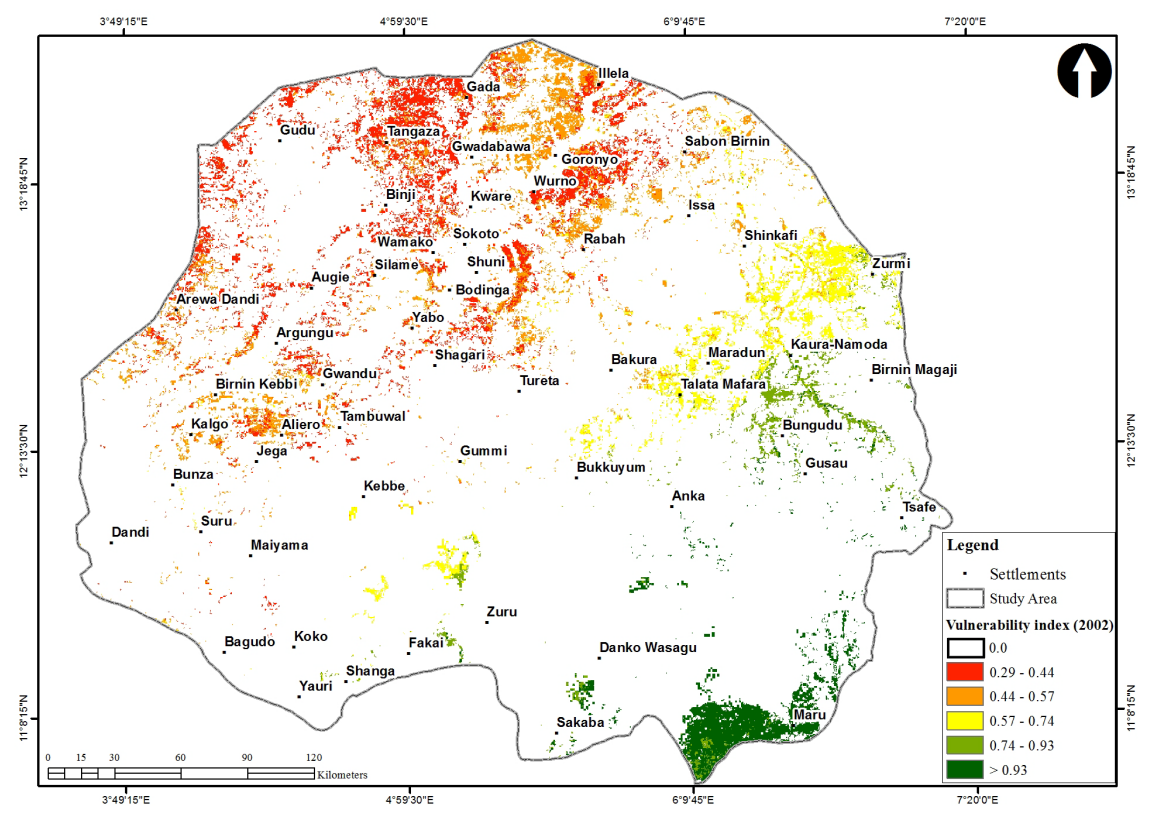

Figure 3. Ecosystem vulnerability index to land degradation in the Sokoto-Rima basin for the year 2002 . 


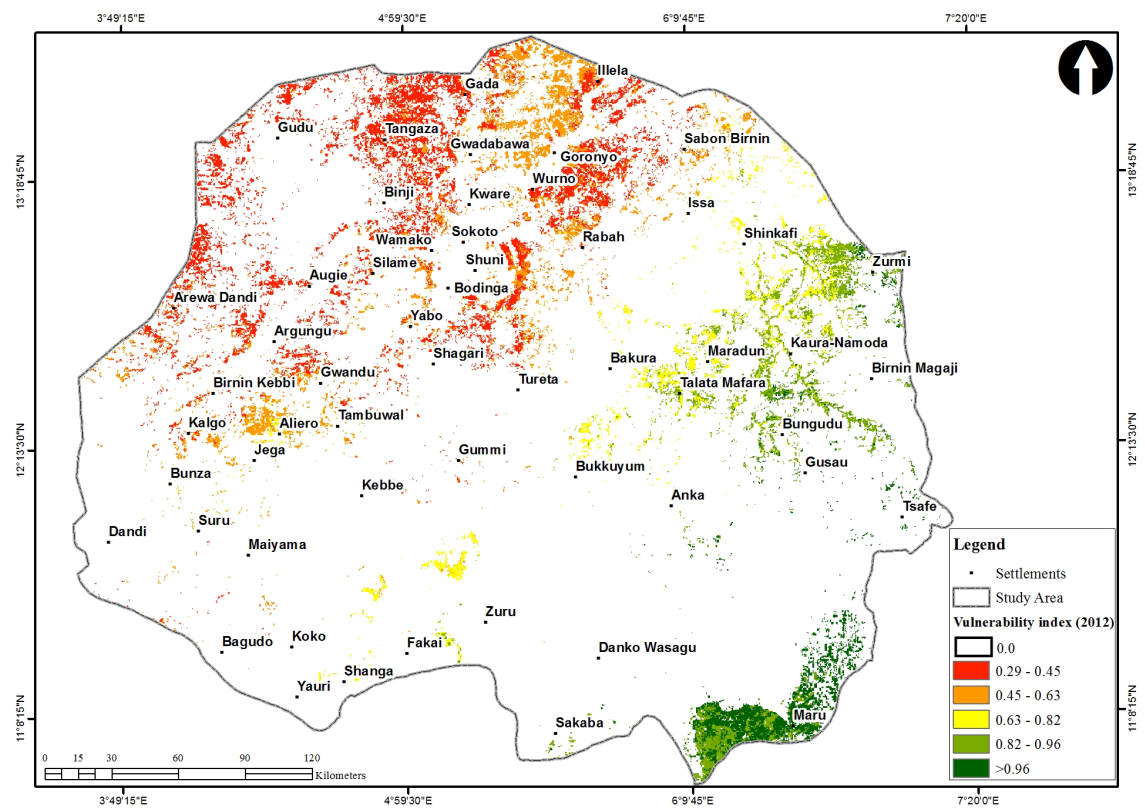

Figure 4. Ecosystem vulnerability index to land degradation in the Sokoto-Rima basin for the year 2012 .

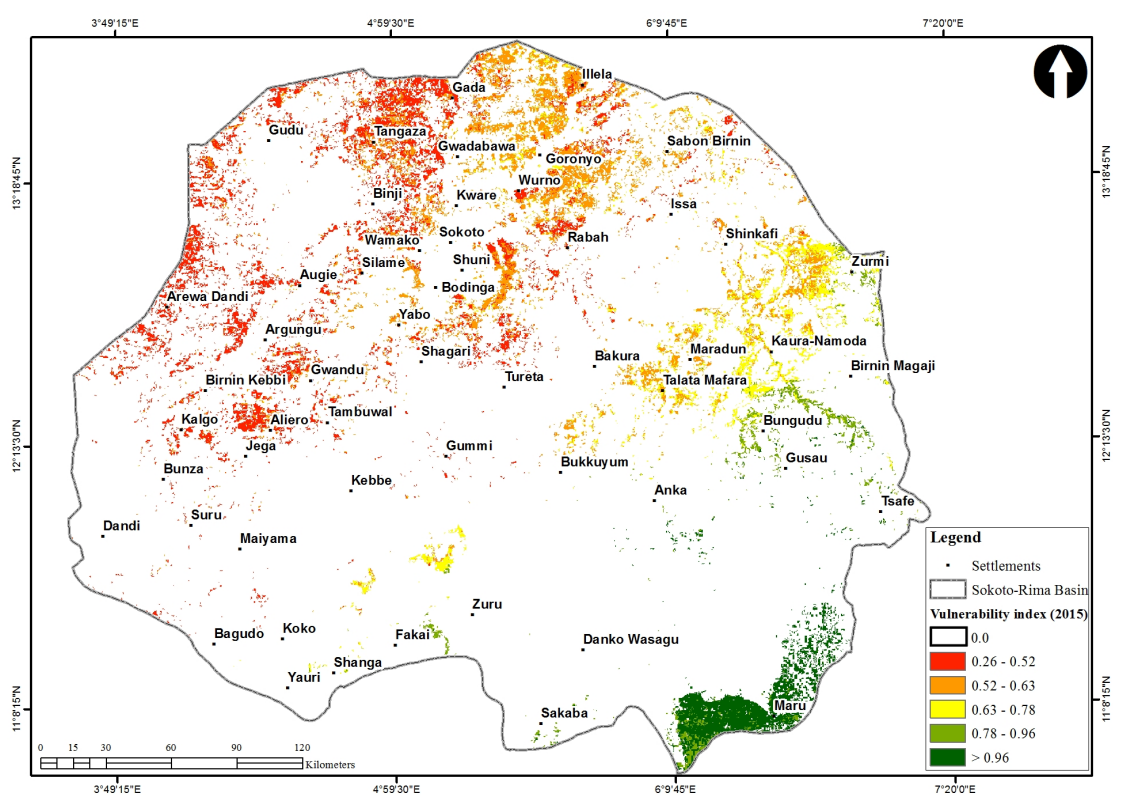

Figure 5. Ecosystem vulnerability index to land degradation in the Sokoto-Rima basin for the year 2015 .

to land degradation in these areas. However, locations with lowest index values of 0.96 and above reduced in spread. Though located in the southern end of the study area, places such as Zurmi, Talata Mafara and Maradun experienced a high index of vulnerability. Locations such as Fakai and Shanga had lower vulnerability index returned to the baseline value in 2002 .

Statistical distribution of the vulnerability indices was summarised and classified in Table 4 for each of the static years of the study. The baseline year 2002 
showed that $88.86 \%$ of the basin have extremely high vulnerability index, while $3.85 \%, 3.19 \%, 1.75 \%, 1.52 \%$ and $0.83 \%$ of the study area were classified as very high, high, moderate, very low and low respectively. By 2012, the basin became more vulnerable with $89.27 \%$ of the study area classified as extremely high status, this increase was at the expense of other vulnerability statuses except low which increased to $2.22 \%$, this tallies with observations in (Figure 4). Three years afterwards, (2015), the basin experienced miniature changes within the high vulnerability status; extremely high $89.27 \%$, very high status reduced to $2.61 \%$, high status increased to $3.33 \%$, moderate status improved to $2.5 \%$, low status shrink to $0.79 \%$ and very low status increased to $1.51 \%$ (a similar value to the baseline).

\subsection{Changes in Vulnerability}

The nature and variation of IVI for the Sokoto-Rima basin are summarised in Table 5. Overall, the IVI ranges between 0.2341 in 2002 and remains unchanged in 2012 and 2015 with 1.0 value. This suggests that the ecosystem grew worse overtime across the study area. This assertion is further confirmed when the variation of IVI was assessed to be 0.7659 from 2002 to 2012. On aggregate, the totalled index of vulnerability remained constant suggesting that the basin remains highly vulnerable to land degradation driven by climate change and its associated componential factors.

Spatial changes in the vulnerability index thereby become more germane to examine locations and extent of changes that have occurred overtime in the basin. Statistics of the change and the associated proportion is presented in Table 6 while the graphical analysis of the spatial changes is displayed in Figure 6. From 2002 to 2012, land with extremely high vulnerability index increased by 384.48 $\mathrm{km}^{2}(0.46 \%)$. Similarly, areas with low vulnerability index increased by 1306.4 $\mathrm{km}^{2}(166.89 \%)$ while there were reductions in land areas with specific indices: very high $-670.88 \mathrm{~km}^{2}(-18.53 \%)$, high $-165.11 \mathrm{~km}^{2}(-5.5 \%)$, moderate -821.14 $\mathrm{km}^{2}(-50.03 \%)$ and very low $-33.74 \mathrm{~km}^{2}(-2.37 \%)$. However, from 2012 to 2015 , there were changes in the nature of vulnerability in the basin. Moderate vulnerability increased drastically by $186.45 \%\left(1529.19 \mathrm{~km}^{2}\right)$, very low vulnerability areas increased also by $1.87 \%\left(26.09 \mathrm{~km}^{2}\right)$ and areas with high vulnerability also increased by $10.28 \%\left(291.71 \mathrm{~km}^{2}\right)$. These increases occurred at the expense of other areas: very high $-16.86 \%\left(-497.22 \mathrm{~km}^{2}\right)$, and low vulnerability level $-1348.69 \mathrm{~km}^{2}$ (-64.55\%). Overall, the spatial changes observed in the basin showed that from 2002 to 2015 , the index of susceptibility to land degradation increased drastically as areas of extremely high status increased by $383.40 \mathrm{~km}^{2}$, high increased by $126.60 \mathrm{~km}^{2}$, moderate status increased by $708.04 \mathrm{~km}^{2}$ (Figure 6). Areas with low vulnerability status and very low further decreased in land areas. This scenario suggests that Sokoto-Rima basin has gradually becomes more vulnerable to climate change driven land degradation.

The extent of spatial changes is further displayed in Figure 7 which showcases 
locations of the varying change dimension in vulnerability index in the basin. Despite the fact that about $80 \%$ of the landscape showed no change in status, most of the areas with improvements in extent of vulnerability were located northwards. Reductions in indices were mostly observed in the eastern and western axis while locations southward of the basin showed more of no change in vulnerability indices than slight reductions. This tallies with the study conducted by [39] which showed that changes in climate and biodiversity of the northwest of Nigeria are initiating a shift in its ecological delineation.

Table 4. Area and percentage distribution of ecosystem vulnerability in 2002, 2012, and 2015.

\begin{tabular}{ccccccc}
\hline \multirow{2}{*}{$\begin{array}{c}\text { Vulnerability } \\
\text { status }\end{array}$} & $\begin{array}{c}\text { Land Area } \\
\left(\mathrm{km}^{2}\right)\end{array}$ & $\%$ & $\begin{array}{c}\text { Land Area } \\
\left(\mathrm{km}^{2}\right)\end{array}$ & $\%$ & $\begin{array}{c}\text { Land Area } \\
\left(\mathrm{km}^{2}\right)\end{array}$ & $\%$ \\
\hline $\begin{array}{c}\text { Extremely } \\
\text { high }\end{array}$ & $83,553.72$ & 88.86 & $83,938.20$ & 89.27 & $83,937.12$ & 89.27 \\
Very high & 3620.20 & 3.85 & 2949.32 & 3.14 & 2452.10 & 2.61 \\
High & 3002.04 & 3.19 & 2836.93 & 3.02 & 3128.64 & 3.33 \\
Moderate & 1641.30 & 1.75 & 820.15 & 0.87 & 2349.34 & 2.50 \\
Low & 782.81 & 0.83 & 2089.21 & 2.22 & 740.52 & 0.79 \\
Very low & 1426.43 & 1.52 & 1392.69 & 1.48 & 1418.78 & 1.51 \\
Total & $\mathbf{9 4 , 0 2 6 . 5}$ & 100.00 & $\mathbf{9 4 , 0 2 6 . 5}$ & 100.00 & $\mathbf{9 4 , 0 2 6 . 5}$ & 100.00 \\
\hline
\end{tabular}

Table 5. Integrated vulnerability index values and their respective variation between 2002 and 2015 .

\begin{tabular}{cccccc}
\hline & & \multicolumn{2}{c}{ IVI } & \multicolumn{2}{c}{ Variation of IVI } \\
\cline { 2 - 5 } Year & 2002 & 2012 & 2015 & $2002-2012$ & $2012-2015$ \\
\hline Sokoto-Rima basin & 0.2341 & 1.0 & 1.0 & 0.7659 & 0.0
\end{tabular}

Table 6. Change dimension of ecosystem vulnerability status from 2002 to 2015.

\begin{tabular}{ccccccc}
\hline $\begin{array}{c}\text { Vulnerability } \\
\text { status }\end{array}$ & $\begin{array}{c}\text { 2002-2012 } \\
(\text { Land Area }) \\
\mathbf{k m}^{2}\end{array}$ & $\begin{array}{c}\text { \% Change } \\
(2002-2012)\end{array}$ & $\begin{array}{c}2012-2015 \\
(\text { Land Area }) \\
\mathbf{k m}^{2}\end{array}$ & $\begin{array}{c}\text { \% Change } \\
(2012-2015)\end{array}$ & $\begin{array}{c}\text { 2002-2015 } \\
(\text { Land Area }) \\
\mathbf{k m}^{2}\end{array}$ & $\begin{array}{c}\text { \% Change } \\
(2002-2015)\end{array}$ \\
\hline $\begin{array}{c}\text { Extremely } \\
\text { high }\end{array}$ & 384.48 & 0.46 & -1.08 & 0.00 & 383.40 & 0.46 \\
$\begin{array}{c}\text { Very high } \\
\text { High }\end{array}$ & -670.88 & -18.53 & -497.22 & -16.86 & -1168.10 & -32.27 \\
Moderate & -165.11 & -5.50 & 291.71 & 10.28 & 126.60 & 4.22 \\
Low & -821.14 & -50.03 & $1,529.19$ & 186.45 & 708.04 & 43.14 \\
Very low & -3306.40 & 166.89 & -1348.69 & -64.55 & -42.29 & -5.40 \\
Total & 0.00 & -2.37 & 26.09 & 1.87 & -7.65 & -0.54 \\
\hline
\end{tabular}




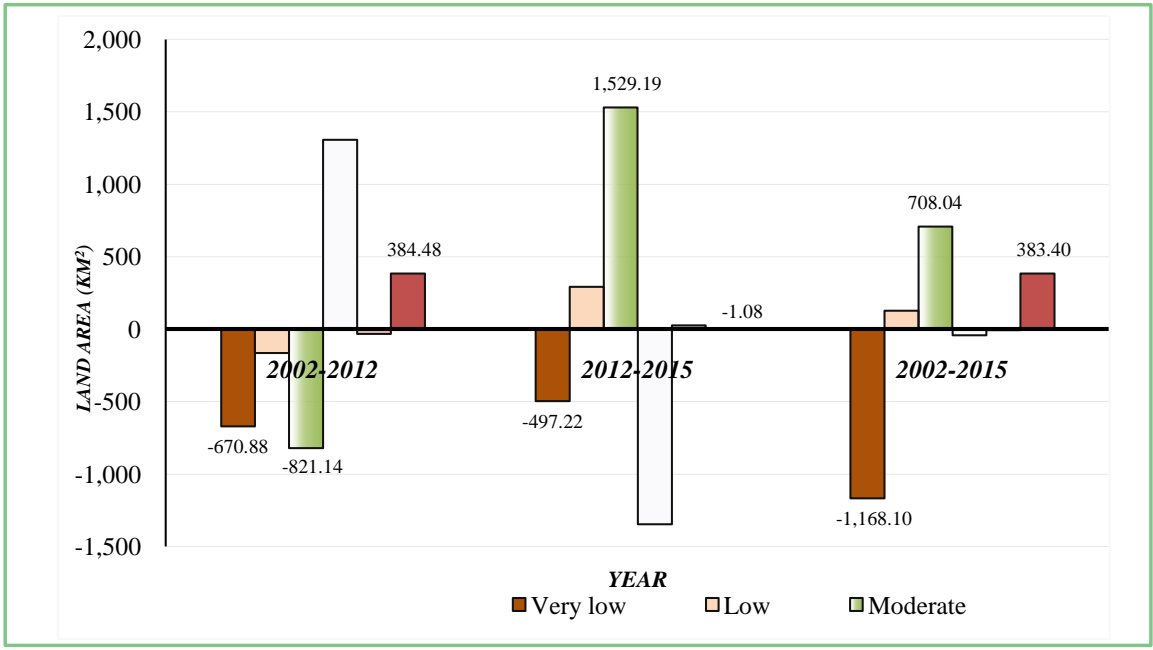

Figure 6. Spatial changes in ecosystem vulnerability index for the year 2002 to 2015 .

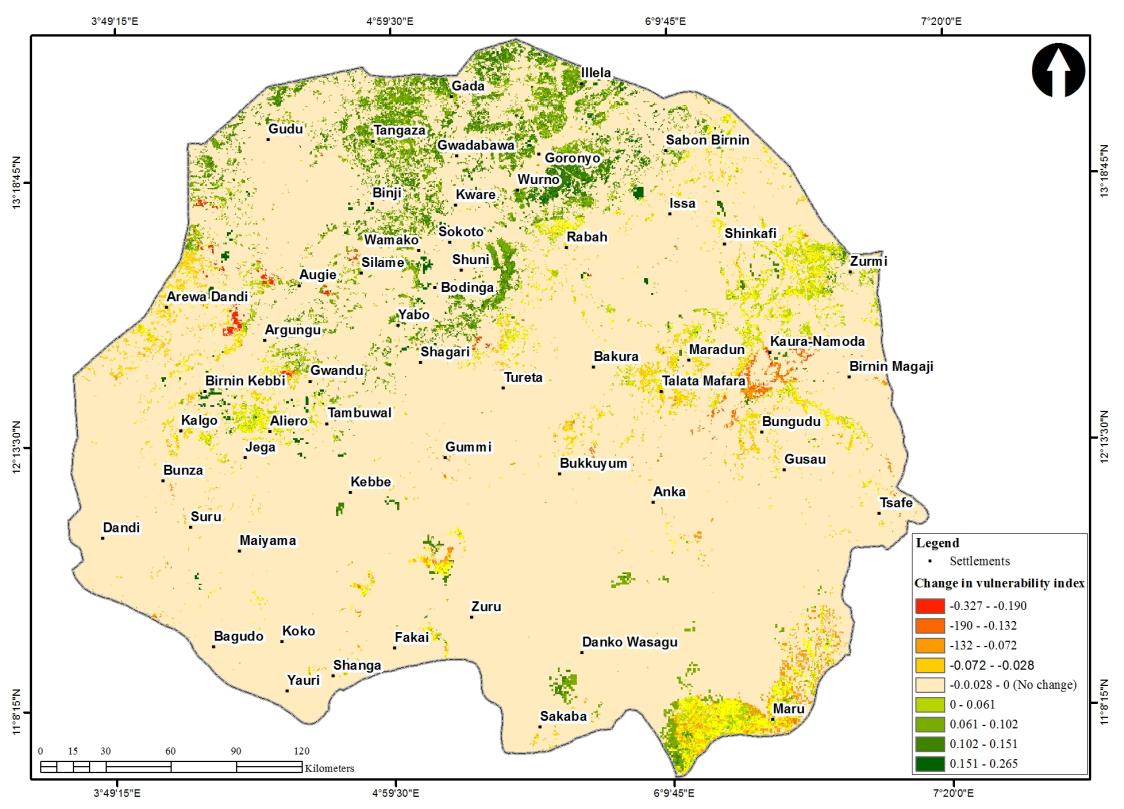

Figure 7. Spatial changes in ecosystem vulnerability index for the year 2002 to 2015.

\section{Conclusions}

In this study, we have demonstrated the spatial assessment of vulnerability of the semi-arid ecosystem of the Sokoto-Rima basin to land degradation using geospatial technology with variables that were developed from natural and anthropogenic sources. Changes in vulnerability index were examined spatially and temporally from 2002 to 2015 for the entire study area.

The outcome of the show cases the extent of fragility of the basin to vagaries of climate change as dictated by vulnerability components as defined by the [4]. It showed that the entire region is extremely vulnerable to land degradation albeit with traces of improvements in some parts of the eastern and central area. However, there exists a north-south vulnerability dichotomy in the index in- 
creases northwards and decreases southwards. This geography is highly related to the extent of climate variability observed in the Sokoto-Rima basin where water availability decreases northwards and temperature increases in the same fashion. Specifically, the study showed that the area is gradually becoming less vulnerable with high vulnerability reduced to mid-index values by 2012 from 2002. This period also typifies the period where the UNCCD made a strong commitment towards combating desertification [3]. Improvements were observed in key towns and capital cities. Spots of improvements were also observed in some parts of the western axis of the study area by 2015. This showed that 2015 is a key year towards sustainability planning of the basin towards ecosystem enhancement and restoration by limiting anthropogenic activities such as reliance on wood for energy sources and development of large-scale woodlots and shelter-belts within the basin. [25] showed that the Sahara is gradually advancing southwards to some communities in Sokoto State which in the years before were not found to experience such a phenomenon. This calls for action on greenbelt development and provision of climate-smart local energy sources.

The study year 2015 coincidences with initiation of the United Nations SDGs (sustainable development goals) points to the possibility synergy and integration of composite environmental knowledge for the development of the basin. Place-based vulnerability index when adapted to the SDGs has the potential to resolve a number of the environmental and human welfare issues. As shown in this study, the basin is well exposed to the determinants and factors that stimulate land degradation. Such knowledge can be aligned and linked to the specific goals of SDGs which are concerned with climate action and livelihood enhancement. It is on this line that [40] stated that better ecosystem management strategies could be earmarked from the SDGs via the targets and indicators. Therefore, sustainability science could be adopted to build resilience for the basin to alleviate poverty and ensure integrated sustainability of the basin.

\section{Acknowledgements}

The authors gratefully acknowledged the permission granted by the European Space Agency (ESA) for granting access to landcover data. The following organizations are also acknowledged for the provision of data on terrain, climate, soil, and population respectively; Japanese Aerospace Exploration Agency (JAXA), United States Geological Survey (USGS), Princeton Climate Analytics (PCA), and National Bureau of Statistics of Nigeria (NBS).

\section{Conflicts of Interest}

The authors declare no conflicts of interest regarding the publication of this paper.

\section{References}

[1] Xu, D. and Wang, Z. (2019) Identifying Land Restoration Regions and Their Driv- 
ing Mechanisms in Inner Mongolia, China from 1981 to 2010. Journal of Arid Environments, 167, 79-86. https://doi.org/10.1016/j.jaridenv.2019.04.021

[2] Zhao, A., Zhang, Z., Feng, L., Zhao, Y., Li, Q. and Jia, Z. (2018) Spatiotemporal Change of Aeolian Desertification Land Distribution in Northern China from 2001 to 2015. Journal of the Indian Society of Remote Sensing, 46, 1555-1561. https://doi.org/10.1007/s12524-018-0793-z

[3] United Nations Convention to Combat Desertification (UNCCD) (2010) Launching the UN Decade for Deserts and the Fight against Desertification. UNCCD News. http://www.un.org/apps/news/story.asp?NewsID=35633\&Cr=desert\&Cr1

[4] Intergovernmental Panel on Climate Change (IPCC) (2007) Climate Change 2007: Impacts, Adaptation and Vulnerability. Working Group II Contribution to the Fourth Assessment Report of the IPCC. Cambridge University Press, Cambridge.

[5] Ladisa, G., Todorovic, M. and Liuzzi, G.T. (2015) A GIS-Based Approach for Desertification Risk Assessment in Apulia Region, SE Italy. Physics and Chemistry of the Earth, 49, 103-113. https://doi.org/10.1016/j.pce.2011.05.007

[6] Vicente-Serrano, S.M., Cabello, D., Tomás-Burguera, M., Martín-Hernández, N., Beguería, S., Azorin-Molina, C. and Kenawy, A.E. (2015) Drought Variability and Land Degradation in Semiarid Regions: Assessment Using Remote Sensing Data and Drought Indices (1982-2011). Remote Sensing, 7, 4391-4423. https://doi.org/10.3390/rs70404391

[7] Li, S.S., Yang, S.N., Liu, X.F., Liu, Y.X. and Shi, M.M. (2015) NDVI-Based Analysis on the Influence of Climate Change and Human Activities on Vegetation Restoration in the Shaanxi-Gansu-Ningxia Region, Central China. Remote Sensing, 7, 11163-11182. https://doi.org/10.3390/rs70911163

[8] Intergovernmental Panel on Climate Change (IPCC) (2014) Summary for Policymakers. In: Edenhofer, O., Pichs-Madruga, R., Sokona, Y., Farahani, E., Kadner, S., Seyboth, K., Adler, A., Baum, I., Brunner, S., Eickemeier, P., Kriemann, B., Savolainen, J., Schlömer, S., von Stechow, C., Zwickel, T. and Minx, J.C., Eds., Climate Change 2014: Mitigation of Climate Change. Contribution of Working Group III to the Fifth Assessment Report of the Intergovernmental Panel on Climate Change, Cambridge University Press, Cambridge and New York, $31 \mathrm{p}$.

[9] Dixon, A.P., Faber-Langendoen, D., Josse, C., Morrison, J. and Loucks, C.J. (2014) Distribution Mapping of World Grassland Types. Journal of Biogeography, 41, 2003-2019. https://doi.org/10.1111/jbi.12381

[10] White, R.P., Murray, S. and Rohweder, M. (2000) Pilot Analysis of Global Ecosystems: Grassland Ecosystems. World Resources Institute, Washington DC, $81 \mathrm{p}$.

[11] Ekpoh, I.J. and Nsa, E. (2011) Extreme Climatic Variability in North-Western Nigeria: An Analysis of Rainfall Trends and Patterns. Journal of Geography and Geology, 3, 51-62. https://doi.org/10.5539/jgg.v3n1p51

[12] Farauta, B.K., Egbule, C.L., Idrisa, Y.L. and Agu, V.C. (2011) Climate Change and Adaptation Measures in Northern Nigeria: Empirical Situation and Policy Implications. African Technology Policy Studies Network, $31 \mathrm{p}$.

[13] Abdullahi, S.A., Muhammad, M.M., Adeogun, B.K. and Mohammed, I.U. (2014) Assessment of Water Availability in the Sokoto Rima River Basin. Resources and Environment, 4, 220-233.

[14] Abaje, I.B., Sawa, B.A., Iguisi, E.O. and Ibrahim, A.A. (2015) A Quantitative Approach to Vulnerability Assessment of Rural Communities to Climate Change in Kaduna State, Nigeria. Nigerian Geographical Journal, 10, 180-195.

[15] Atedhor, G.O. (2015) Agricultural Vulnerability to Climate Change in Sokoto State, 
Nigeria. African Journal of Food, Agriculture, Nutrition and Development, 15, 9855-9871.

[16] Adeniyi, P.O. and Omojola, A. (1999) Land Use/Land Cover Change Evaluation in Sokoto Rima Basin of N.W. Nigeria Based on Archival Remote Sensing and GIS Techniques. In: Adeniyi, Ed., Geoinformation Technology Applications for Resources and Environmental Management in Africa, AARSE, Wura-Kay Press, Lagos, 143-172.

[17] Shitangsu, K.P. (2013) Vulnerability Concepts and Its Application in Various Fields: A Review on Geographical Perspective. Journal of Life and Earth Science, 8, 63-81. https://doi.org/10.3329/jles.v8i0.20150

[18] Thomas, K., Hardy, R.D., Lazrus, H., Mendez, M., Rivera-Collazo, I., Roberts, J.T., Rockman, M., Warner, B.P. and Winthrop, R. (2019) Explaining Differential Vulnerability to Climate Change: A Social Science Review. WIREs Climate Change, 10 , 1-18. https://doi.org/10.1002/wcc.565

[19] Dolan, A.H. and Walker, I.J. (2003) Understanding Vulnerability of Coastal Communities to Climate Change Related Risks. Proceedings of the 8 th International Coastal Symposium, Vol. 3, 1316-1323.

[20] Fellmann, T. (2012) The Assessment of Climate Change-Related Vulnerability in the Agricultural Sector: Reviewing Conceptual Frameworks. In: Maybeck, A., Lankoski, J., Redfern, S., Azzu, N. and Gitz, V., Eds., Building Resilience for Adaptation to Climate Change in the Agricultural Sector, Proceedings of a Joint FAO/OECD Workshop, FAO, Roma, 37-61. http://www.fao.org/docrep/017/i3084e/i3084e.pdf

[21] Sarewitz, D., Pielke, R. and Keykhah, M. (2003) Vulnerability and Risk: Some Thoughts from a Political and Policy Perspective. Risk Analysis, 23, 805-810. https://doi.org/10.1111/1539-6924.00357

[22] Cutter, S.L., et al. (2008) A Place-Based Model for Understanding Community Resilience to Natural Disasters. Global Environmental Change, 18, 598-606. https://doi.org/10.1016/j.gloenvcha.2008.07.013

[23] Adger, W.N. (2006) Vulnerability. Global Environmental Change, 16, 268-281. https://doi.org/10.1016/j.gloenvcha.2006.02.006

[24] AbdulKadir, A., Abdullahi, J., Christie, I.Y., Mohammed, M., Liman, H.M. and Hassan, A.B. (2015) Climate Change and Vulnerability of the Riverine Communities in Niger State, Nigeria. Nigeria Geographic Journal, 10, 14-23.

[25] Yelwa, S.A. and Eniolorunda, N.B. (2012) Simulating the Movement of Desertification in Sokoto and Its Environs, Nigeria Using $1 \mathrm{~km}$ SPOT NDVI Data. Environmental Research Journal, 6, 175-181. https://doi.org/10.3923/erj.2012.175.181

[26] Abubakar, M.J., Mokhtar, J. and Lam, K.C. (2018) Monitoring the Health of Dryland Ecosystem across North-Western Nigeria Using Multi-Temporal MODIS-NDVI Remote Sensing Data. FUDMA Journal of Sciences, 2, 262-272.

[27] Hamidu, H., Garba, M.L., Abubakar, Y.I., Muhammad, U. and Mohammed, D. (2016) Groundwater Resource Appraisals of Bodinga and Environs, Sokoto Basin North Western Nigeria. Nigerian Journal of Basic and Applied Science, 24, 92-101. https://doi.org/10.4314/njbas.v24i2.13

[28] Japan International Cooperation Agency (JICA) (2014) The Project for Review and Update of Nigeria National Water Resources Master Plan: Volume 5 Supporting Report. Federal Ministry of Water Resources, Abuja.

[29] Di Gregorio, A., Henry, M., Donegan, E., Finegold, Y., Latham, J., Jonckheere, I. and Cumani, R. (2016) Land Cover Classification System: Classification Concepts Software Version (3). Food and Agriculture Organisation, Rome, 40 p. 
[30] Foley, J.A., et al. (2011) Solutions for a Cultivated Planet. Nature, 478, 337-342. https://doi.org/10.1038/nature10452

[31] de Smith, M.J., Goodchild, M.F., Longley, P.A., et al. (2018) Geospatial Analysis-A Comprehensive Guide to Principles, Techniques and Software Tools. 6th Edition, The Winchelsea Press, Edinburgh, 608 p.

[32] Ren, X., Dong, Z., Hu, G., Zhang, D. and Li, Q. (2016) A GIS-Based Assessment of Vulnerability to Aeolian Desertification in the Source Areas of the Yangtze and Yellow Rivers. Remote Sensing, 8, 626. https://doi.org/10.3390/rs8080626

[33] Linstone, H.A. and Turoff, M. (1975) The Delphi Method: Techniques and Applications. Addison-Wesley, London.

[34] Saaty, T.L. (1977) A Scaling Method for Priorities in Hierarchical Structures. Journal of Mathematical Psychology, 15, 234-281. https://doi.org/10.1016/0022-2496(77)90033-5

[35] Ye, J. (2010) Multicriteria Fuzzy Decision-Making Method Using Entropy Weights-Based Correlation Coefficients of Interval-Valued Intuitionistic Fuzzy Sets. Applied Mathematical Modelling, 34, 3864-3870. https://doi.org/10.1016/j.apm.2010.03.025

[36] Pham, D.L. (2001) Spatial Models for Fuzzy Clustering. Computer Vision and Image Understanding, 84, 285-297. https://doi.org/10.1006/cviu.2001.0951

[37] Ramanathan, R.A. (2001) Note on the Use of the Analytic Hierarchy Process for Environmental Impact Assessment. Journal of Environmental Management, 63, 27-35. https://doi.org/10.1006/jema.2001.0455

[38] Hou, K., Li, X., Wang, J. and Zhang, J. (2016) Evaluating Ecological Vulnerability Using the GIS and Analytic Hierarchy Process (AHP) Method in Yan'an, China. Polish Journal of Environmental Studies, 25, 599-605. https://doi.org/10.15244/pjoes/61312

[39] AbdulKadir, A., Usman, M.T. and Shaba, A.H. (2015) An Integrated Approach to Delineation of the Ecoclimatic Zones in Northern Nigeria. Journal of Ecology and the Natural Environment, 7, 247-255. https://doi.org/10.5897/JENE2015.0532

[40] Keesstra, S.D., Bouma, J., Wallinga, J., Tittonell, P., Smith, P., Cerdà, A., Montanarella, L., Quinton, J.N., Pachepsky, Y., van der Putten, W.H., Bardgett, R.D., Moolenaar, S., Mol, G., Jansen, B. and Fresco, L.O. (2016) The Significance of Soils and Soil Science towards Realization of the United Nations Sustainable Development Goals. Soil, 2, 111-128. https://doi.org/10.5194/soil-2-111-2016 